\title{
Using the Eco-Innovation Index to Assess the Eco-Innovation Performance: Case of Slovakia
}

\author{
Lubica LESAKOVA and Peter LACO
}

Matej Bel University, Faculty of Economics, Department of Corporate Economics and Management, Banska Bystrica, Slovakia

Received date: 12 February 2020; Accepted date:21 July 2020; Published date: 27 August 2020

Academic Editor: Paweł Kobis

Copyright (C 2020. Lubica LESAKOVA and Peter LACO. Distributed under Creative Commons Attribution 4.0 International CC-BY 4.0

\begin{abstract}
Eco-innovation becomes an emerging priority of the European Union (EU) policy. To secure the environmental protection and economic growth eco-innovations have a central role. As the numerous practical examples demonstrate, eco-innovation is a powerful instrument that combines reduced negative impact on the environment and the positive impact on the economy and society. Emphasizing eco-innovation as a means for achieving sustainable development requires information on the performance of main actors, in particular, countries. Measuring country's performance of eco-innovation has started via indices or scoreboards. Policy and innovation actors can thus learn about diagnosing different areas of eco-innovation, monitoring trends and directions. The aim of this paper is to assess the ecoinnovation performance during the last three years in Slovakia by means of eco-innovation index, to analyse and assess the components and indicators of eco-innovation index for Slovakia in the year 2018 and to compare them with those of EU 28-average. Identified and discussed will be the areas in which the main weaknesses and strengths are evident. Based on the research results formulated will be the main implications for managers and policy makers in Slovakia to improve the state in mentioned area. Our study is based on secondary sources of data coming from the Eurostat and Eco-Innovation Observatory. The study is qualitative and descriptive in nature; methods used in the paper are the method of casual analysis, deduction, abstraction, comparison as well as the synthesis.
\end{abstract}

Keywords: eco-innovation index, eco-innovation performance, assessing eco-innovation performance.

\section{Introduction}

Europe's economic growth over many decades has been fuelled by the intensive use of resources. However today it faces multiple challenges of stimulating the growth, while ensuring that this growth is economically and ecologically sustainable. 
Energy use, water scarcity, land shortages, the depletion of materials and the management of waste are among the most discussed issues posing sustainability challenges.

The EU's economic prosperity and well being is linked to its natural environment and the global demand for renewable energy and resource-efficient solutions will be a source of jobs and economic growth in the years to come. To secure (reaching) the environmental protection and economic growth, eco-innovations have a central role. Eco-innovation becomes an emerging priority of EU policy relating to different aspects of almost all industries.

A significant step forward for ecoinnovation is the Eco-Innovation Action Plan (EcoAP) launched by the European Commission in December 2011. Ecoinnovation Action Plan is an important element of the European policy framework for sustainable consumption and production. It aims to transfer Europe into a more competitive resource-efficient economy and acknowledges the key role of eco-innovation in the context of job creation, growth and competitiveness, as well as environmental protection.

At the macro level it is necessary to understand environmental, economic and social dimensions in which eco-innovation strategies may develop. The new global economy is not only a knowledge economy, but also an economy based on responsible behaviour. In the knowledge-based development, the key to growth and prosperity relies on the issues of acquiring, creating, developing, storing and applying knowledge for a sustainable economic, social and environmental development.

To step towards sustainable economic growth, there is a need for much more ecoinnovations to appear in all sectors of EU.

The aim of the article is to assess the ecoinnovation performance in Slovakia by means of eco-innovation index. To fulfil the main aim of the paper we formulated three partial aims:
1. To assess the overall eco-innovation performance of Slovakia during the last 3 years, to analyse and assess all the components and indicators of ecoinnovation index for Slovakia in the year 2018 and to compare them with those of EU 28 - average.

2. To identify main strengths and weaknesses of eco-innovation performance for Slovakia.

3. To formulate main implications for managers and policy makers in Slovakia to improve the state in mentioned area.

The methods used in the paper are the method of casual analysis, deduction, abstraction, comparison as well as the synthesis.

\section{Theoretical background}

Eco-innovation is a concept that is difficult to define because of the complexity of the subject. Fussler and James (1996) define eco-innovation as "new products and processes which provide customer and business value but significantly decrease environmental impacts". Hillebrand and Driessen (2002) state that green innovation "does not have to be developed with the goal of reducing the environmental burden" but it "does however, yield significant environmental benefits". Kemp and Pearson (2007) extend the view on eco-innovation from products and processes to the "assimilation or exploitation of a (...) service or management or business method" and include the consideration of the life cycle aspects. Arundel and Kemp (2009) emphasize that eco-innovation "can be motivated by economic or environmental considerations".

Rennings (2000) perceives eco-innovations as new approaches that help reduce environmental burdens or achieve ecological targets and differentiate between technological, organizational, social, and institutional ones.

Originally, the concept of eco-innovation focused on progress in the field of technology and processes, with an intention to reduce environmental impacts 
of economic activities (Terjesen and Patel, 2017; Del Rio Gonzales, 2009). In time, ecoinnovation's awareness has essentially broadened, particularly where the following aspects are concerned (Azevedo et al., 2014):

- Eco-innovation does not only apply to clean and resource-efficient technologies that are specifically aimed at reducing environmental harm (Horbach, 2008). Every product or service generating an environmental benefit (reduced use of natural resources and lower use of emissions and waste) in relation to relevant alternatives should be recognized as an eco-innovation (Kemp and Pearson, 2007).

- Eco-innovation encompasses all environmental improvements across the whole product life cycle, concerning the way they are designed, produced, used, reused, and recycled (Ecoinnovation Observatory, 2011).

- Eco-innovation, in a broader perspective, also embraces environmentally oriented organizational and marketing approaches, including eco-innovative business models, which can have effects on the consumer behaviour (Ecoinnovation Observatory, 2013).

Concentrating on most of these additional aspects, the expert group of the EcoInnovation Observatory defines ecoinnovation as the following. Eco-innovation is the introduction of any new or significantly improved product (good or service), process, organizational change or marketing solution, that reduces the use of natural resources (including materials, energy, water and land) and decreases the release of harmful substances across the whole life-cycle (Eco-innovation Observatory, 2011).

Emphasizing eco-innovation as a means for achieving sustainable development requires information on the performance of main actors, in particular, countries (Kemp, 2010; León-Ledesma and Satchi, 2019). Measuring country's performance of eco-innovation has started via indices or scoreboards, which come with indicators and scores and help with benchmarks across countries. Policy and innovation actors can thus learn about diagnosing different areas of eco-innovation, monitoring trends and directions and drawing lessons about the strengths and weaknesses across countries (Park et al., 2017).

Measuring eco-innovation enables to assess the progress of the components of eco-innovation (Cheng and Shiu, 2012). In practice it helps policy makers to understand the overall trend of ecoinnovation, its drivers and barriers and to design effective policies and framework conditions especially encouraging for companies to increase their eco-innovation efforts (Wagner, 2008).

Eco-innovation can be measured at different levels: firm, national, regional and international (Hammond, 1995). Measuring eco-innovation at the national level provides information on which countries are leaders, followers, loungers or laggards (Jang et al., 2015).

Various stakeholders including governments, enterprises, investors, NGOs, etc. exist in the field of eco-innovation. The results of measuring eco-innovation can be meaningful and useful to multiple stakeholders (Phillips, 2003). The role of the government is crucial for implementing and diffusing eco-innovation at the national level. Governments can develop a national system that enables the production of ecofriendly goods and services. Governments can establish and implement policy instruments for eco-innovation, such as environmental regulations, financial schemes and programs for supporting R\&D and fostering eco-markets (Jang, 2015). Business and industry play a crucial role in reducing impacts on resource use and the environment, through more efficient production processes, preventive strategies and cleaner production technologies and procedures (Kogan et al., 2017; Wagner, 2008). Citizens as consumers have demands on eco-products, and may become involved in innovation activities. Consumer behaviour contributes 
to building green markets (Rogge, Reichardt, 2016). NGOs set the environmental issues in the society and collaborate with other actors to create sustainable life. Investors can influence eco-innovation through green investment (Inderst et al., 2012). Therefore, the ecoinnovation index can be used by multiple stakeholders. It provides useful information for all stakeholders to encourage further actions.

\section{Methodology of research}

To measure the eco-innovation performance in all EU member states, the Eco-Innovation Observatory has developed a composite index, so called "Ecoinnovation index" (EII). The Ecoinnovation index demonstrates the ecoinnovation performance of a country compared with the EU average and with the EU top performers. It is equated in scores and shows how well individual member states perform in different dimensions of eco-innovation compared to the EU average (EU EII is equated with 100, EU EII=100). Eco-innovation index is a composite index that is based on 16 indicators which are aggregated into five components: eco-innovation inputs, ecoinnovation activities, eco-innovation outputs, resource efficiency outcomes and socio-economic outcomes. The composition of eco-innovation index offers the insight in eco-innovation performance of a country and enables the eco-innovation assessment.

According to a technical note from the Ecoinnovation Scoreboard (Giljum and Lieber, 2016), country-specific figures of the single indicator are weighted with the share of population to calculate an EU average which corrects for the bias of smaller member states. Therefore, the EU average of sub-indicators presents the weighted mean of all country specific data of the EU member states. The EU average of indicators that display absolute numbers is built directly by summing up the underlying data.

The index presents the situation of ecoinnovation at the national level. The value of the index can influence decision-making in the field of eco-innovation. The ecoinnovation index helps to assess the status of eco-innovation performance, identify areas for improvement as needed, to facilitate comparison of countries' ecoinnovation performance over time and to motivate eco-innovation activities (Park et al., 2017).

The study is qualitative and descriptive in nature and most of the date is based on secondary sources of data coming from Eurostat and Eco-Innovation Observatory.

\section{Results and discussion}

The Eco-Innovation Observatory is publishing (starting the year 2010) the ecoinnovation index for all EU member states. In the year 2018, all EU countries were clustered into three groups (Ecoinnovation Observatory, 2018a):

1. Eco-innovation leaders, with score significantly higher than the EU average (a score of > 114);

2. Average eco-innovation performers with scores around the EU average (a score between 85 and 114);

3. EU countries with performance around $85 \%$ or less compared to the EU average (with a score $<85$ ). 


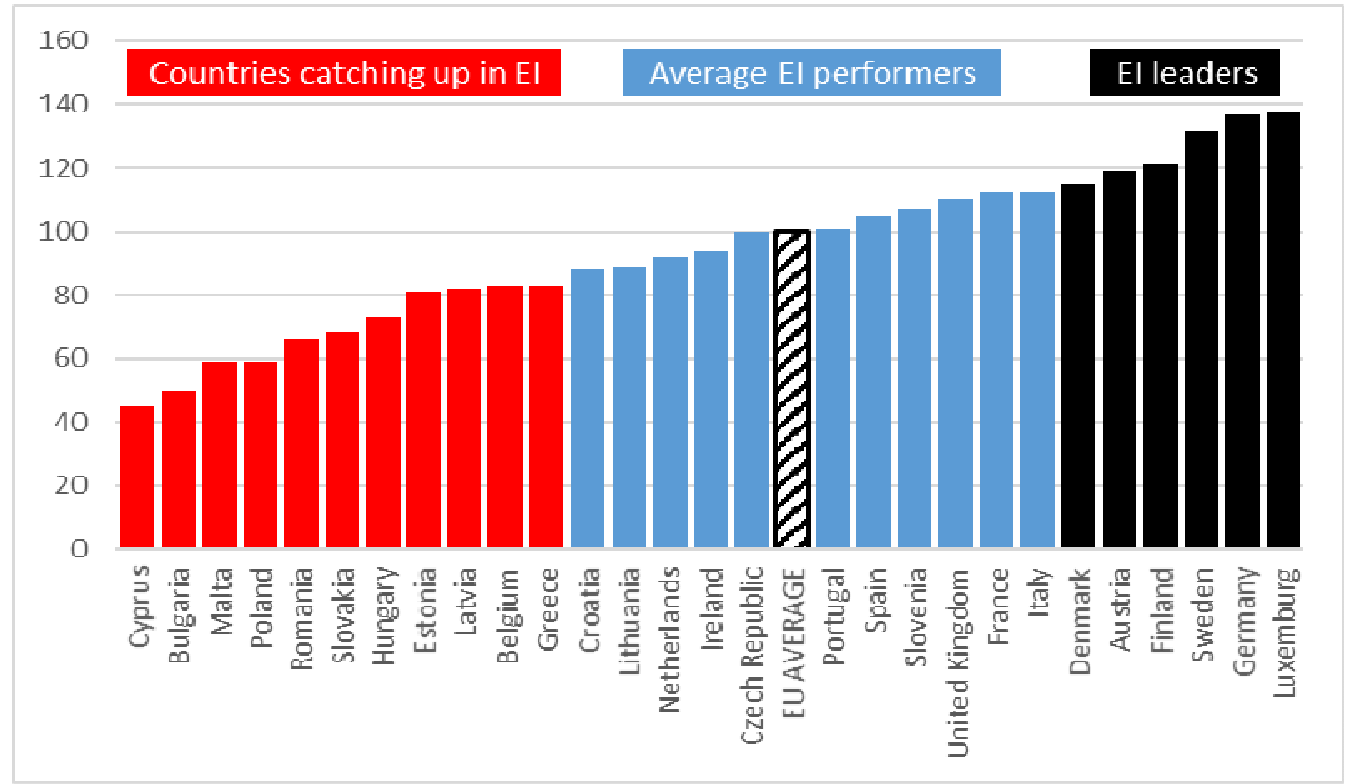

Fig. 1: EU 28 Eco-innovation index 2018, composite index.

Source: Own elaborating based on EIO data.

According to the Eco-Innovation Index in the year 2018, Luxembourg leads the ranking of all EU countries with an aggregated score of 138. Germany (137), Sweden (132) and Finland (121) follow the Luxembourg. Eleven EU member states obtained scores around the EU average of 100 and were labelled as average ecoinnovation performers. The aggregated eco-innovation scores in this group range from 112 (France and Italy) to 88 (Croatia). Eleven countries in the last group of countries represent countries catching up in eco-innovation. Aggregated scores in this group of countries range from 83 (Belgium) to 45 (Cyprus).
Slovakia with an overall score of 68 in 2018 is on the 23th place among $28 \mathrm{EU}$ member states. The score of 68 means that Slovakia's overall eco-innovation performance is $32 \%$ below the EU average. The country's performance has improved compared to 2010 when the overall score was only 43; in the year 2015 the ecoinnovation index has increased to 72 and in the year 2016 was 85 , but during the last three years the index has decreased every year and with the score 68 in 2018 Slovakia belongs to the last group of countries with low eco-innovation performance (Lesáková, 2018).

Table 1: Eco-innovation index (score) - Slovakia

\begin{tabular}{|l|c|c|c|c|c|c|c|c|c|}
\hline & $\mathbf{2 0 1 0}$ & $\mathbf{2 0 1 1}$ & $\mathbf{2 0 1 2}$ & $\mathbf{2 0 1 3}$ & $\mathbf{2 0 1 4}$ & $\mathbf{2 0 1 5}$ & $\mathbf{2 0 1 6}$ & $\mathbf{2 0 1 7}$ & $\mathbf{2 0 1 8}$ \\
\hline EU changing composition & 100 & 100 & 100 & 100 & 100 & 100 & 100 & 100 & 100 \\
\hline Slovakia & 43 & 49 & 50 & 42 & 61 & 72 & 85 & 74 & 68 \\
\hline
\end{tabular}

Source: Own elaborating based on EIO data.

The eco-innovation index is an aggregated index giving a general overview of the overall eco-innovation performance across the EU and it does not allow to identify strong or weak areas. It offers the disaggregation of the composite index into five components - sub-indices (Table 2). 
Table 2. Scores in the five components of the eco-innovation index in Slovakia (2016-2018)

\begin{tabular}{|c|c|c|c|c|c|c|}
\hline Year & $\begin{array}{c}\text { Eco- } \\
\text { innovation } \\
\text { inputs }\end{array}$ & $\begin{array}{c}\text { Eco- } \\
\text { innovation } \\
\text { activities }\end{array}$ & $\begin{array}{c}\text { Eco- } \\
\text { innovation } \\
\text { outputs }\end{array}$ & $\begin{array}{c}\text { Resource } \\
\text { efficiency } \\
\text { outcomes }\end{array}$ & $\begin{array}{c}\text { Socio- } \\
\text { economic } \\
\text { outcomes }\end{array}$ & $\begin{array}{c}\text { Eco- } \\
\text { innovation } \\
\text { index }\end{array}$ \\
\hline 2016 & 29 & 91 & 28 & 121 & 142 & $\mathbf{8 5}$ \\
\hline 2017 & 27 & 90 & 33 & 87 & 124 & $\mathbf{7 4}$ \\
\hline 2018 & 25 & 71 & 57 & 99 & 82 & $\mathbf{6 8}$ \\
\hline
\end{tabular}

Source: Own elaborating based on EIO data.

Figure 2 illustrates scores of the five subindices (components) in the eco-innovation index 2018: eco-innovation inputs, eco- innovation activities, eco-innovation outputs, resource-efficiency outcomes and socio-economic outcomes.

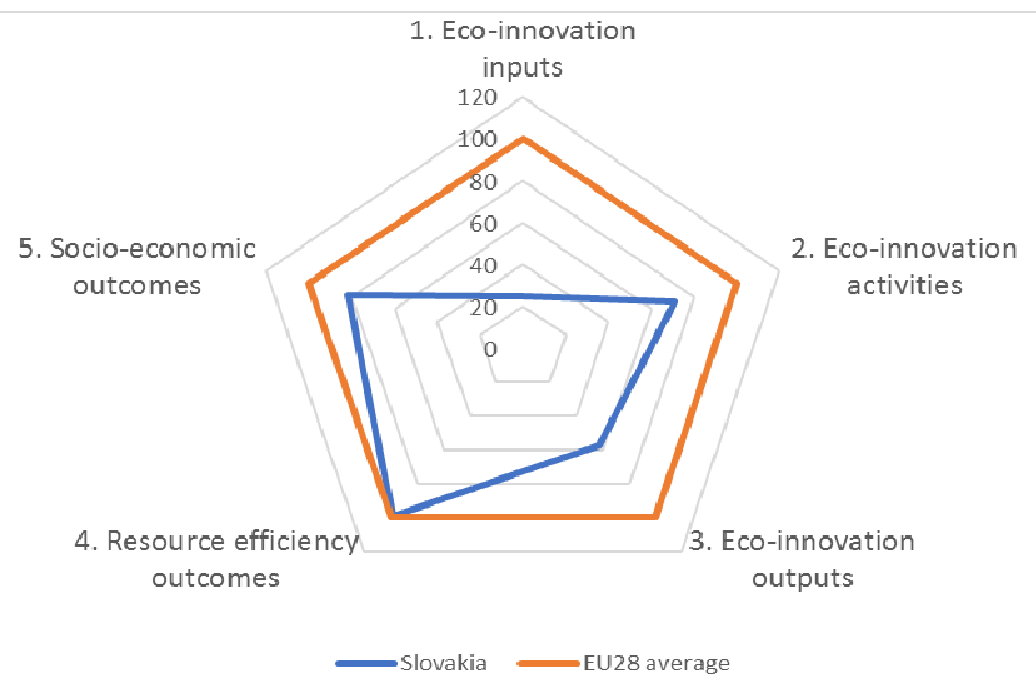

Fig. 2. Components of the Eco-innovation index for Slovakia 2018. Source: Own elaborating based on EIO data.

Critical may be viewed that Slovakia is below the EU average in all components of eco-innovation index. In order to illustrate the diversity across the EU countries, the minimum and maximum scores as well as the overall score range is illustrated for each of the five components and also for the aggregated index (table 3 ).

Table 3. Scores in the five components of the Eco-Innovation Index 2018 Slovakia

\begin{tabular}{|l|c|c|c|c|c|c|}
\hline & $\begin{array}{c}\text { Eco- } \\
\text { innovation } \\
\text { inputs }\end{array}$ & $\begin{array}{c}\text { Eco- } \\
\text { innovation } \\
\text { activities }\end{array}$ & $\begin{array}{c}\text { Eco- } \\
\text { innovation } \\
\text { outputs }\end{array}$ & $\begin{array}{c}\text { Resource } \\
\text { efficiency } \\
\text { outcomes }\end{array}$ & $\begin{array}{c}\text { Socio- } \\
\text { economic } \\
\text { outcomes }\end{array}$ & $\begin{array}{c}\text { Eco- } \\
\text { innovation } \\
\text { index }\end{array}$ \\
\hline Slovakia & 25 & 71 & 57 & 99 & 82 & $\mathbf{6 8}$ \\
\hline Minimum-EU & 0 & 10 & 9 & 5 & 1 & $\mathbf{4 5}$ \\
\hline Maximum-EU & 175 & 179 & 224 & 190 & 177 & $\mathbf{1 3 8}$ \\
\hline Range-EU & 175 & 168 & 216 & 185 & 176 & $\mathbf{9 4}$ \\
\hline
\end{tabular}

Source: Own elaborating based on EIO data.

Eco-innovation inputs show to what extent the government gives the priority to investments in support of environmental and energy R\&D. It also gives information 
about R\&D human resources in this area. This component is composed of three subindices: government environmental and energy R\&D appropriations and outlays (as share of GDP), total environmental and energy R\&D personnel and researchers (as a share of total employment) and total value of green early-stage investments (in USD/capita).

The eco-innovation input component had a score of 25 in 2018 in Slovakia (compared to a score of 29 in 2016). Government environmental and energy R\&D appropriations and outlays, as a share of GDP, were $0.01 \%$ in 2017 (compared to $0.04 \%$, the EU average). The performance was slightly better for the share of $R \& D$ personnel and researchers out of total employment, with $0.72 \%$ in 2014 compared to an EU average of 1.32\% (Ecoinnovation Observatory, 2018b). The value for green early-stage investments was during the last three years very low (1 USD/capita) (SBA, 2018).

Eco-innovation activities include indicators to monitor the scope and scale of ecoinnovation activities undertaken by companies. This component shows to what extent companies in Slovakia are involved in material and energy efficiency ecoinnovation, as well as in observing environmental management. The indicators include: a) enterprises that introduced an innovation with environmental benefits obtained within the enterprise ( $\%$ of total firms); b) enterprises that introduced an innovation with environmental benefits obtained by the end user (\% of total firms); c) ISO 14001 registered organisations (per mil. population).

Overall component index is 71 for the year 2018, which is the third highest (after resource efficiency outcomes and socioeconomic outcomes) among the rest of the sub-indexes. Enterprises that introduced an innovation with environmental benefits obtained within the enterprise and those obtained environmental benefits by the end user are almost the same 0.23 and 0.22 (it is twice lower as EU average 0.53 and 0.50). The third indicator of this component is the number of ISO 14001registered organisations per million inhabitants. Slovakia is doing well in this indicator. There were 427 ISO 14001 registered companies per million inhabitants in 2016, which gives an index score of 0.76 , which is well above of EU average 0.30 (Eco-innovation Observatory, 2018b).

Eco-innovation outputs are used to monitor the extent to which knowledge outputs generated by businesses and researchers relate to eco-innovation. Eco-innovation outputs quantify the outputs of ecoinnovation activities in terms of patents (per mln population), publications (per mln population) and media coverage (per numbers of electronic media).

Eco-innovation outputs reached an index score of 57. Slovakia's low score in ecoinnovation outputs is explained by the relatively low performance in all three dimensions of EI outputs (eco-patents, EI publications and EI media coverage). The number of eco-patents obtained in 2014 was 2.09 eco-patents per million people. In comparison to the EU average, number of EI patents obtained per million populations amounted to 15.34 in the same year (Ecoinnovation Observatory, 2018b).

Resource-efficiency outcomes relate to wider effects of eco-innovation on improved resource productivity. This component measures material, water and energy productivity and greenhouse gas (GHG) emissions intensity.

The overall component score for Slovakia was 99 in 2018, what was a slight improvement since 2015 when it was 78, but it is a decrease to the year 2016, when it was 121 . Material productivity amounts to $1.76 \mathrm{EUR} / \mathrm{kg}$ in 2015, which is below the EU average of $2.25 \mathrm{EUR} / \mathrm{kg}$, while energy productivity is 7.85 Eur/toe (the EU average of $9.66 \mathrm{EUE} / \mathrm{toe}$ ) in 2015 (SBA, 2018). The GHG emissions intensity is slightly higher in comparison to EU average, amounting to $0.34 \mathrm{CO} 2$ emissions generated per unit of GDP. 
Socio-economic outcomes of eco-innovation represent effects of eco-innovation activities for society and the economy. This includes changes in employment turnover or export that relate to broadly understood ecoinnovation activities. The indicators for this component include: export of products from eco-industries $(\%$ of total exports); employment in eco-industries and circular economy (\% of total employment); revenue in eco-industries and circular economy (\% of total revenue across all companies).

The overall component score for socioeconomic outcomes for Slovakia in 2018 is 82. This is a rapid decline since 2016, when Slovakia scored 142 for this component. Employment in eco and circular economy industries was at $2.93 \%$ of total employment in Slovakia in 2016 that is slightly above the EU average of $2.69 \%$. Eco-industries' revenue has achieved $4.73 \%$ of total revenue across sectors, which is higher in comparison to the EUaverage $2.30 \%$. The share of products from eco-industry in total export was $0.40 \%$ in 2016, which is below the EU average of 0.60\% (Eco-innovation Observatory, 2018b).

It can be stated that the eco-innovation performance has decreased during the last three years and Slovakia faces many challenges from wide range of environmental and economic problems.

Eco-innovation inputs and outputs are the weakest components in overall ecoinnovation index. Eco-innovation inputs account only $14.3 \%$ of EU average for 2018. This is mainly due to low public funding in environmental and energy R\&D. Government budget appropriations and outlays for R\&D (usual public funding in Slovakia) lag far behind the EU's average (they are twice lower than the EU average). The public funding is supplemented by the EU funds (mainly the European Structural Funds and Horizont 2020). There is also evident a lack of human resources in research and development. Highly educated persons in the field of engineering and science present a very low share in the national workforce of population, partly due to a tendency of a "brain-drain" in Slovakia (MŽP, 2019a). Better conditions, international exposure, and a creation of a more competitive environment could improve this situation. As the indicators show, the green earlystage investments are in Slovakia very low.

As the result of low financial support into the environmental and energy R\&D as well as low percentage of workforce in research and development, the eco-innovation outputs related to eco-innovation (ecopatents, EI publications and EI media coverage) is very low ( $26 \%$ of EU average).

What concerns the resource-efficiency outcomes, there are many challenges for Slovakia. The big challenge is to increase the energy and material productivity as well as the green gas (GHG) emissions intensity. Slovakia is committed to the goals of the EU 2030 Agenda and to the 2020 climate and energy package. Share of renewable energy is coming closer to $14 \%$ target for the year 2020 and is mostly covered by Slovakia's traditional clean energy sector based on large hydropower plants and supplemented by a small hydro power biomass and solar. Air protection represents one of the main challenges the largest sources of such pollution are the transport sector and the residential heating) (MŽP, 2019b). In October 2017, an amendment to the Air Act was approved. This deals with specific measures to combat the air pollution such as reducing nitrogen oxide emissions to comply with currently applicable national emission ceilings reducing nitrogen dioxide and ozone concentrations as well as with reducing transport and energy related emissions.

The rapid decline is seen for the component socio-economic outcomes (it was 82 in the year 2018 to 142 in the year 2016). Employment in eco and circular economy industries was 9\% more in 2016 than the EU average, and what concerns the eco-industry's revenue it was twice more than EU average; the decline of this component in the year 2018 is the result of decrease in employment in eco- and circular economy as well as in the decrease 
of total revenue across all sectors in the country.

At the same time there is only one strength to be mentioned; Slovakia outperforms many EU countries in a number of companies with ISO 14001 certification demonstrating aspiration to higher environmental standards in business sector (index Slovakia : EU average $=2.53$ ) (SBA, 2018). This contributed positive to the average score in the Eco-innovation activities.

Thought Slovakia has implemented many of EU policies and measures in the area of environmental policy and eco-innovations to the SR legal system, the progress is slow (Lesáková, 2019). Insufficient approximation of the EU directives to the SR legal system in relation to environmental protection and ecoinnovation has been criticized by the European Commission. Environmental policy stringency in Slovakia has been assessed as above average compared to OECD countries. According to the World Bank, we lag behind other countries in the quality or regulations and law enforcement.

The need for a new, modern environmental strategy which reflects the actual situation and urgent problems of the whole system of environment has resulted at the new "Envirostrategy 2030 for Slovakia" (MŽP 2019a), which was approved in February 2019. The strategy identifies basic system problems, sets 2030 targets, proposes framework measures to improve the current situation and contains also basic performance indicators for verification of achieved results. The strategy underlines the role of eco-innovations.

\section{Conclusion}

It can be stated that eco-innovations in Slovakia face many challenges. Based on the above analysis, the main implications for policy makers and managers in Slovakia may be formulated as follows.

Policy makers in Slovakia should place greater emphasis on sufficient approximation of EU directions to the legal system of the SR. They have to create effective policy programs and measures supporting eco-innovation and helping to establish a stable platform for ecoinnovation's development.

Public funding and expenditure in the ecoresearch and development is still low in Slovakia. To tackle with this issue both state as well as public and private institutions have to be more involved in the financial support.

It is necessary to raise firm's awareness about eco-innovations and green business as business with a high added value in relation to the corporate responsibility concept as well as to raise firm's awareness about the necessity to implement stabile and continual environmental business strategy.

In cooperation with central government authorities and professional organizations, academia and non-governmental organizations, the more efficient system of formal and informal environmental education and training for sustainable development has to be implemented.

Eco-innovations call attention to the positive contribution that the companies can make to sustainable development and a competitive economy (Jaffe et al., 2005). Hence, eco-innovation is understood as the combined improvement of economic and environmental performance of society.

The findings of our study contribute to the theory of using the eco-innovation index as a mean to assess the eco-innovation performance of the country. The results of this study give insights into the key areas of eco-innovation index and can help to understand the scope of eco-innovation performance. Measuring eco-innovation enables to monitor the changes in ecoinnovation performance and helps with benchmarks across countries. Policy and eco-innovation actors can learn about diagnosing different areas of ecoinnovation, monitoring trends and indicate strengths and weaknesses. The results of assessing eco-innovation can be thus a 
meaningful and useful to managers and policy makers to encourage further actions.

The main limitation of this study is the absence of benchmarks in assessing the eco-innovation performance across EU countries. For the future, we aim to spread our research also to benchmarks across some neighbouring countries (V4 countries). Despite the limitations, our paper contributes to extending the scope and scale of eco-innovation studies. It offers insights into the application of ecoinnovation index.

\section{References}

- Arundel, A. and Kemp, R. (2009), 'Measuring eco-innovation,' UNUMERIT, working papers series, Maastricht. [Online], [Retrieved November 18, 2019], http://www.merit.unu.edu/publicatio ns/ wppdf/2009/wp2009-017.pdf.

- Azevedo, S. et al. (2014), EcoInnovation and the Development of Business Models, Springer International Publishing, Switzerland.

- Del Rio Gonzales, P. (2009), 'The empirical analysis of the determinants for environmental technological change: a research agenda,' Ecological Economics, 68 (2009), 861-878.

- Eco-innovation Observatory. (2011), 'Eco-Innovation Action Plan', [Online], [Retrieved September 11, 2019], https://ec.europa.eu/environment/ec oap/about-action-plan/objectivesmethodology_andactions/.

- Eco-innovation Observatory. (2013), 'Europe in transition. Paving the way to a green economy through ecoinnovation,' [Online], [Retrieved March 10, 2019], https://www.ecoinnovation.eu/ index.php/reports/ecoinnovation-briefs/.

- Eco-innovation Observatory. (2018a), 'EU Eco-Innovation Index 2017. EIO Brief,' [Online], [Retrieved March 21, 2019],

https://ec.europa.eu/environment/ec oap/scoreboard_en/.

- Eco-innovation Observatory. (2018b), 'Eco-innovation Country Profile 20162017. Slovakia,' [Online], [Retrieved
January 11, 2019], https://ec.europa.eu/environment/ec oap/country/profiles/.

- Fussler, C. and James, P. (1996), Driving eco-innovation: a breakthrough discipline for innovation and sustainability, Pitman Ltd., London.

- Giljum, S. and Lieber, M. (2016), 'The Eco-Innovation Scoreboard: 2014 and 2015 Versions Technical Note,' [Online], [Retrieved May 11, 2019], https://ec.europa.eu/environment/ec oap/sites/

ecoap_stayconnected/files/ecoinnovation/.

- Hammond, A. (1995), Environmental Indicators: A systematic Approach to Measuring and Reporting on Environmental Policy Performance in the Context of Sustainable Development, World Resource Institute, New York.

- Hillebrand, B. and Driessen,P. (2002), 'Adoption and diffusion of green innovations,' Marketing for sustainability: towards transactional policy making, Nielsen, W. and Bartels, G. (ed), IOS Press Inc., Amsterdam.

- Horbach, J. (2008), 'Determinants of Environmental Innovation - New Evidence from German Panel Data Sources,' Research Policy, 37 (2008), 163-173.

- Horbach, J. (2016), 'Empirical determinants of eco-innovation in European countries using the community innovation survey,' Environmental Innovation and Societal Transitions, 19 (2016), 1-14.

- Cheng, CC. and Shiu, EC. (2012), 'Validation of a proposed instrument for measuring eco-innovation: An implementation perspective,' Technovation, 32 (2012), 329-334.

- Inderst, G., Kaminker, Ch. and Stewart, F. (2012), 'Defining and Measuring Green Investments: Implications for Institutional Investors Asset allocations,' OECD Working Papers on Finance, Insurance and Private Pensions, OECD Publishing, Paris.

- Jaffe, A.B., Newell, R. and Stavins, R. (2005), 'A tale of two market failures: technology and environmental policy', 
Ecological Economics, 54 (2-3), 164174.

- Jang, EK., Park, MS., Roh, TW. and Han, KJ. (2015), 'Policy instruments for ecoinnovation in Asian countries,' Sustainability, 7 (2015), 12586-12614.

- $\quad$ Kemp, R. and Pearson, P. (2007), 'Final Report of the MEI project Measuring Eco-Innovation,' UNU-MERIT, working papers series, Maastricht.

- Kemp, R. (2010), 'Eco-innovation: Definition, measurement and open research issues', Economia Politica, 27 (2010), 397-420.

- Kogan, L. et al. (2017), 'Technological Innovation, Resource Allocation, and Growth,' The Quarterly Journal of Economics, 132 (2), 665-712.

- León-Ledesma, MA. and Satchi, M. (2019), 'Appropriate Technology and Balanced Growth,' The Review of Economic Studies, 86 (2), 807-835.

- Lesáková, L. (2018), 'The critical view on Innovation Activity in SME's Sector in Slovakia,' Modeling Innovation Sustainabity and Technologies. Economic and Policy Perspectives, Dias, A. and Salmelin, B., (ed.), Springer International Publishing, Switzerland.

- Lesáková, L'. (2019), Ekologické inovácie v činnosti malých a stredných podnikov, Ekonomická fakulta Univerzity Mateja Bela, Banská Bystrica.

- MŽP - Ministerstvo životného prostredia SR. (2019a), 'Envirostratégia 2030, [Online], [Retrieved May 15, 2019], https://www.minzp.sk/iep/strategick e-materialy/envirostrategia-2030/.
- MŽP - Ministerstvo životného prostredia SR. (2019b), 'Obehové hospodárstvo - budúcnost' rozvoja Slovenska', Slovenská agentúra životného prostredia, Bratislava.

- $\quad$ Park, MS., Bleischwitz, R., Han, KJ. and Joo, JH. (2017), 'Eco-innovation Indices as Tools for Measuring EcoInnovation,' Sustainability 9 (2017), doi: 10.3390/su9122206.

- Phillips, R. (2003), Community Indicators, The American Planning Association, Chicago, IL.

- Rennings, K. (2000), 'Redefining innovation - eco innovation research and the contribution from ecological economics,' Ecological Economics, 32 (2), 319-332.

- Rogge, KS. and Reichardt, K. (2016), 'Policy mixes for sustainability transitions: An extended concept and framework for analysis,' Research Policy, 45 (8), 1620-1635.

- SBA - Slovak Business Agency. (2018), 'Analýza využívania eko-inovácií a obehovej ekonomiky v prostredí MSP,' [Online], [Retrieved April 10, 2019], http://www.sbagency.sk/sites/default /files/ 7_anal_vyuzivania_eko-inovaciia-prvkov-obehovej-ekonomiky/pdf/.

- Terjesen, S. and Patel, PC. (2017), 'In search of Process Innovations: The Role of Search Depth, Search Breadth, and the Industry Environment,' Journal of Management, 43 (5), 1421-1446.

- Wagner, M. (2008), 'Empirical Influence of environmental management on innovation. Evidence from Europe,' Ecological Economics, 66 (2-3), 392-402. 